\title{
Early post-hatching starvation delays p70 S6 kinase activation in the muscle of neonatal chicks
}

\author{
Karine Bigot ${ }^{1}$, Mohammed Taouis ${ }^{1,2}$, Michel Picard ${ }^{1}$ and Sophie Tesseraud ${ }^{1 *}$ \\ ${ }^{1}$ Régulation du Métabolisme des Oiseaux, Station de Recherches Avicoles, Institut National de la Recherche \\ Agronomique, Centre de Tours-Nouzilly, 37380 Nouzilly, France \\ ${ }^{2}$ Laboratoire de Biologie Cellulaire et Moléculaire, Biotechnologies, Institut National de la Recherche Agronomique, \\ Domaine de Vilvert, 78352 Jouy-en-Josas, France
}

(Received 17 February 2003 - Revised 23 June 2003 - Accepted 30 July 2003)

\begin{abstract}
Chicken muscle ribosomal protein S6 kinase (S6K1) has been recently characterised and its enzymic activity is regulated by the nutritional and hormonal (insulin) status in vivo. The regulation of S6K1 is still unknown in neonatal chicks. The present study aimed to compare the activation of S6K1 in early-feeding (EF) and $48 \mathrm{~h}$-delayed-feeding (DF) chicks from hatching to $4 \mathrm{~d}$ of age. During post-hatching starvation, S6K1 activity remained at the basal level measured in the control-hatched chicks. The maximum S6K1 activity was recorded on the first day of feeding with an increase of about 2.5-fold in the EF and DF chicks $(P<0 \cdot 01)$. S6K1 activity was correlated with plasma insulin level, suggesting a probable insulin-dependent S6K1 activation. The feeding-induced increase in S6K1 activity was related to its Thr389 residue phosphorylation. A similar pattern for protein kinase B phosphorylation was observed, upstream from S6K1. The S6K1 pathway was stimulated to the same extent in the EF and DF chicks, which indicates that post-hatching starvation did not increase S6K1 activation. It is concluded that muscle S6K1 is activated as soon as food is available without improvement in the response of the S6K1 pathway after post-hatching starvation.
\end{abstract}

Chicks: Neonatal feeding: p70 S6 kinase activation: Skeletal muscle

A key element in the control of protein synthesis is cytoplasmic serine-threonine kinase p70 S6 kinase (S6K1). S6K1 is responsible for the in vivo phosphorylation of ribosomal protein S6 (Ballou et al. 1991; Kawasome et al. 1998) and then it regulates the translation of specific mRNA (TOP mRNA) that encode essential components of the protein synthesis apparatus (Dufner \& Thomas, 1999). Protein synthesis and S6K1 in mammals are positively regulated by food intake (Svanberg et al. 1997), partly through the increase in plasma insulin level. Insulin activates S6K1 via a well-documented pathway that involves phosphatidylinositol 3'-kinase, protein kinase B (also termed Akt) (PKB) and the mammalian target of rapamycin-FKBP rapamycinassociated protein (Shah et al. 2000). S6K1 regulation by the nutritional state implies that not only insulin, but also nutrients, including amino acids and particularly branched-chain amino acids, play a critical role both in vitro and in vivo (Long et al. 2000; Peyrollier et al. 2000; Kimball \& Jefferson 2002; Proud 2002). However, the precise mechanism by which S6K1 is activated remains unclear in mammals as in other species.

The responsiveness to the nutritional status of skeletalmuscle protein synthesis and the insulin-signalling pathway is particularly pronounced during the neonatal period (Suryawan et al. 2001; Davis et al. 2002). In particular, feeding-induced S6K1 stimulation is significantly higher in 7-d-old than in 26-d-old piglets (Kimball et al. 2002). It has recently been shown that $\mathrm{S} 6 \mathrm{~K} 1$ is expressed in the breast muscle of 3-week-old chickens and is activated by both the nutritional state and insulin (Bigot et al. 2003b). S6K1 stimulation was observed despite the relative insulin resistance of chicken muscle to exogenous insulin (Simon 1989; Taouis et al. 1993) and the lack of a refeedingrelated response of chicken muscle phosphatidylinositol $3^{\prime}$-kinase (Dupont et al. 1998). At the present time, the regulation of S6K1 remains undefined in chick neonates as well as the possible specificity in insulin action. The first week of life in chicks is characterised by intensive growth and tissue development with an increase of body weight by 2-fold (Chamblee et al. 1992; Murakami et al. 1992). Moreover, breast-muscle weight is also increased 5-fold during the first $4 \mathrm{~d}$ of age (Bigot et al. 2003a). During this critical period of $4 \mathrm{~d}$, the residual yolk is completely resorbed and the enzymic functions of the gut are activated (Bigot et al. 2001). In practice, hatching and transportation procedures delay the feeding of chicks by

\footnotetext{
Abbreviations: DF, delayed-feeding; EF, early-feeding; IRS, insulin-receptor substrate; PKB, protein kinase B (also termed Akt); S6K1, p70 S6 kinase; Tris, tri(hydroxymethyl)-aminomethane.

* Corresponding author: Dr S. Tesseraud, fax +3324742 77 78, email tesserau@tours.inra.fr
} 
10 to $60 \mathrm{~h}$. Nutrients in the residual yolk that are supposed to counter the lack of food during this starvation period represent an insufficient contribution to the nutritional requirements for both maintenance and growth in today's fast-growing broiler chicks (Bigot et al. 2001). A delayed food supply reduces chick growth and final body weight (Noy \& Sklan, 1999) and it has previously been reported that the early stages of muscle development are delayed as long as food is not available (Bigot et al. 2003a). The effect of a lack of access to food on the regulation of the initiation of muscle protein translation in neonatal chicks has not been examined. Therefore, the aim of the present experiment was to study S6K1 activation in neonate chicks and determine the possible effect of early posthatching starvation on this activation. The food-deprived chicks remained $2 \mathrm{~d}$ after hatching without food before having access to food for the same period $(2 \mathrm{~d})$. To examine the possible S6K1-insulin interaction, changes in the glucose-insulin balance and in PKB, a kinase upstream from $\mathrm{S} 6 \mathrm{~K} 1$, were also investigated.

\section{Materials and methods}

\section{Chemicals}

Nitrocellulose membranes were purchased from Bio-Rad Laboratories (Hercules, CA, USA) and the pre-made polyacrylamide solution protogel was from Prolabo (National Diagnostic, Gredignon, France). Bovine serum albumin (fraction $\mathrm{V}$, radioimmunoassay grade) and protein $\mathrm{A}$-agarose were purchased from Sigma Chemical Company (St Louis, MO, USA). Anti-S6K1 was from Santa Cruz Biotechnology (Santa Cruz, CA, USA). Anti-phosphoThr389 S6K1, anti-protein kinase B (PKB) and anti-phospho-Ser473 PKB antibodies were obtained from Cell Signaling Technology (Beverly, MA, USA). $\left[\gamma^{33} \mathrm{P}\right]$ ATP was obtained from NEN Life Sciences (Zaventem, Belgium). The S6K1 assay kit was purchased from Upstate Cell Signaling (Lake Placid, NY, USA).

\section{Animals and experimental design}

The conditions of egg incubation, hatching and rearing have been described previously (Bigot et al. 2003a). Briefly, chicks were assigned to one of two nutritional conditions. The first group of chicks ( $n$ 89) were fed ad libitum $6 \mathrm{~h}$ after hatching (the time required for chicks to dry) with a balanced starter diet containing $12 \cdot 12 \mathrm{MJ} / \mathrm{kg}$ metabolisable energy and $220 \mathrm{~g}$ crude protein $/ \mathrm{kg}$ (Table 1). This was the early-feeding (EF) group. The other group of chicks ( $n$ 86) remained without food for $2 \mathrm{~d}$, i.e. $54 \mathrm{~h}$ $(48+6 \mathrm{~h})$ after hatching before receiving the same diet. This was the delayed-feeding (DF) group. Water was freely available to all chicks after hatching. During the experimental period the average amounts of feed intake were $9.6,16.1,20.5$ and $21.4 \mathrm{~g} / \mathrm{d}$ per $100 \mathrm{~g}$ body weight in the EF chicks, and $0,0,18.2$ and $18.5 \mathrm{~g} / \mathrm{d}$ per $100 \mathrm{~g}$ body weight in the DF chicks at 1, 2, 3 and $4 \mathrm{~d}$ of age respectively.
Table 1. Composition of the experimental diet $(\mathrm{g} / \mathrm{kg})$

\begin{tabular}{lc}
\hline Ingredients & \\
\hline Maize & 300 \\
Wheat & 310 \\
Soyabean protein 48 & 320 \\
Soyabean oil & 24.5 \\
Calcium carbonate & 15 \\
Dicalcium phosphate & $17 \cdot 5$ \\
Lysine-HCl & 1.1 \\
DL-Methionine & 1.9 \\
NaCl & 3.5 \\
Trace minerals and vitamins & 6.5 \\
Calculated composition & 12.12 \\
Metabolisable energy (MJ/kg) & 220 \\
Crude protein & 1.19 \\
Lysine (\%) & \\
\hline
\end{tabular}

At $6 \mathrm{~h}$ of age (age 0 ), ten chicks were used to determine plasma parameters and to study the breast muscle S6K1 pathway at the beginning of the experiment. These chicks were the control-hatched chicks. The same determinations were performed at 1, 2, 3 and $4 \mathrm{~d}$ of age (exact biological age, i.e. $24 \pm 2,48 \pm 2,72 \pm 2$, and $96 \pm 2 \mathrm{~h}$ after the beginning of the experiment respectively) in the EF and DF chicks (n 10 per treatment). After blood sampling, the chicks were killed by decapitation and the Pectoralis major muscles (left and right) were removed, quickly frozen in liquid $\mathrm{N}_{2}$ and stored at $-80^{\circ} \mathrm{C}$. All experiments were carried out with due regard to the legislation governing the ethical treatment of animals, and investigators were certificated by the French government to carry out animal experiments.

\section{Determination of plasma glucose and insulin levels}

Plasma glucose levels were measured by the glucose oxidase method using an automated analyser (Beckman glucose analyzer 2; Beckman Instruments, Palo Alto, CA, USA). Plasma insulin levels were determined by radioimmunoassay with a guinea-pig anti-porcine insulin antibody using chicken insulin as the standard (Ruffier et al. 1998).

\section{Western blot analysis}

The frozen tissues were ground in liquid $\mathrm{N}_{2}$. Powdered muscles $(500 \mathrm{mg}$ ) were homogenised on ice with an Ultraturax homogeniser (LaboModerne, Paris, France) in buffer A. Buffer A contained $\mathrm{NaCl}(150 \mathrm{mmol} / \mathrm{l})$, tri(hydroxymethyl)-aminomethane (Tris) ( $\mathrm{pH}$ 7.4) (10 mmol/l), EDTA $(1 \mathrm{mmol} / \mathrm{l})$, ethylene glycol-bis $(\beta$-aminoethyl ether)-N, N, $\mathrm{N}^{\prime}, \mathrm{N}^{\prime}$-tetra-acetic acid $(1 \mathrm{mmol} / \mathrm{l})$, triton $\mathrm{X}-100(1 \%, \mathrm{v} / \mathrm{v}), \mathrm{NP}-40(0.5 \%, \mathrm{v} / \mathrm{v})$, protease inhibitors and phosphatase inhibitors. The protease inhibitors were phenyl methyl sulfonyl fluoride $(2 \mathrm{mmol} / \mathrm{l})$, leupeptin $(10 \mu \mathrm{g} / \mathrm{ml})$ and aprotinin $(10 \mu \mathrm{g} / \mathrm{ml})$. The phosphatase inhibitors were sodium fluoride $(100 \mathrm{mmol} / \mathrm{l})$, sodium phosphate $(10 \mathrm{mmol} / \mathrm{l})$ and sodium orthovanadate $(2 \mathrm{mmol} / \mathrm{l})$. The homogenates were centrifuged at $1000 \mathrm{~g}$ for $30 \mathrm{~min}$ at $4^{\circ} \mathrm{C}$ and the supernatant fractions were then ultracentrifuged for $45 \mathrm{~min}$ at $150000 \mathrm{~g}$. The supernatant 
fractions were sampled and stored at $-80^{\circ} \mathrm{C}$. Protein concentrations were determined using the Bio-Rad protein assay kit (Bio-Rad, Hercules, CA, USA).

For the Western blotting analysis, $40 \mu \mathrm{g}$ muscle protein were separated on $10 \%(\mathrm{w} / \mathrm{v})$ SDS-PAGE and then transferred to a nitrocellulose membrane. Membranes were blocked according to the manufacturer's procedure for $1 \mathrm{~h}$ at room temperature. Each membrane was incubated with an antibody directed toward S6K1, phospho-Thr389 S6K1, PKB or phospho-Ser473 PKB. After washing, the membranes were incubated with a second antibody coupled to peroxidase (1/10000) for $1 \mathrm{~h}$ at room temperature. The bands were visualised by an enhanced chemiluminescence Western blotting kit (Cell Signaling Technology, Beverly, MA, USA) and exposed to Kodak Biomax film (Eastman Kodak, Rochester, NY, USA). The bands were quantified by Scion Image software (Scion Corporation, Frederick, MA, USA).

\section{p70 S6 kinase assay}

S6K1 activity was measured in the muscle extracts by immune kinase assay according to the procedure in the S6 kinase assay kit (Upstate Cell Signaling, Lake Placid, NY, USA). Briefly, the muscles were homogenised in extraction buffer B. Buffer B contained $\mathrm{NaCl}(137 \mathrm{mmol} / \mathrm{l})$, Tris (pH 7.5) (20 mmol/l), $\mathrm{MgCl}_{2}(1 \mathrm{mmol} / \mathrm{l}), \mathrm{CaCl}_{2}$ $(1 \mathrm{mmol} / \mathrm{l})$, sodium orthovanadate $(150 \mathrm{mmol} / \mathrm{l}), \mathrm{NP}-40$ $(1 \%, \mathrm{v} / \mathrm{v})$, glycerol $(10 \%, \mathrm{v} / \mathrm{v})$, phenyl methyl sulfonyl fluoride $(2 \mathrm{mmol} / \mathrm{l})$, and aprotinin in PBS $(10 \mathrm{mg} / \mathrm{ml})$. Following ultracentrifugation $\left(150000 \mathrm{~g}, 1 \mathrm{~h}, 4^{\circ} \mathrm{C}\right)$, equal amounts of protein from the supernatant fractions $(500 \mu \mathrm{g})$ were immunoprecipitated with anti-S6K1 antibody (final dilution 1:50, v/v).

The immune complexes were precipitated with protein $\mathrm{A}-$ agarose and washed twice with buffer $\mathrm{C}$. Buffer $\mathrm{C}$ contained Tris- $\mathrm{HCl}(\mathrm{pH} 7.4)(50 \mathrm{mmol} / \mathrm{l}), \mathrm{NaCl}(150 \mathrm{mmol} / \mathrm{l})$, EDTA $(5 \mathrm{mmol} / \mathrm{l}), \beta$-mercaptoethanol $(0 \cdot 1 \%$, v/v), Triton $\mathrm{X}-100(0.5 \%, \mathrm{v} / \mathrm{v})$, and $\beta$-glycerophosphate $(50 \mathrm{mmol} / \mathrm{l})$.

The immune complexes were then washed twice with buffer $\mathrm{D}$ (Tris- $\mathrm{HCl}(\mathrm{pH} 7.4)(50 \mathrm{mmol} / \mathrm{l}), \mathrm{NaCl}$ $(150 \mathrm{mmol} / \mathrm{l}), \quad$ EDTA $(500 \mathrm{mmol} / \mathrm{l}), \quad \beta$-mercaptoethanol $(0.1 \%, \mathrm{v} / \mathrm{v})$, Triton X-100 $(0.5 \%, \mathrm{v} / \mathrm{v}), \beta$-glycerophosphate $(50 \mathrm{mmol} / \mathrm{l}))$ and then twice with PBS. Precipitated S6K1 was re-suspended in a dilution buffer. This buffer contained

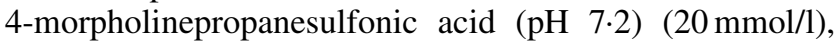
$\beta$-glycerol phosphate $(25 \mathrm{mmol} / \mathrm{l})$, ethylene-glycol-bis(aaminoethyl)-N,N, $\mathrm{N}^{\prime}, \mathrm{N}^{\prime}$-tetra-acetic acid $(5 \mathrm{mmol} / \mathrm{l})$, sodium orthovanadate $(1 \mathrm{mmol} / \mathrm{l})$, and dithiothreitol $(1 \mathrm{mmol} / \mathrm{l})$. This was carried out in the presence of an eleven-aminoacid peptide substrate and an inhibitor cocktail (protein kinase $\mathrm{C}$ inhibitor peptide $(20 \mu \mathrm{mol} / \mathrm{l})$, protein kinase A inhibitor peptide $(2 \mu \mathrm{mol} / \mathrm{l})$ and compound R24571 $(20 \mu \mathrm{mol} / \mathrm{l})$ in the dilution buffer). Reactions were initiated by the addition of an $\mathrm{Mg}-\mathrm{ATP}$ mixture $\left(\mathrm{MgCl}_{2}\right.$ $(75 \mathrm{mmol} / \mathrm{l}), \quad$ ATP $-250 \mu \mathrm{Ci} \quad\left[\gamma^{33} \mathrm{P}\right] \mathrm{ATP} \quad(3000 \mathrm{Ci} / \mathrm{mmol})$ $(500 \mu \mathrm{mol} / \mathrm{l}))$. Samples were incubated for $30 \mathrm{~min}$ at $30^{\circ} \mathrm{C}$ with agitation. The reactions were terminated by spotting a $25 \mu \mathrm{l}$ sample of the reaction mixture on p81 phosphocellulose paper. Following washing (three times with $0.75 \%(\mathrm{w} / \mathrm{v})$ phosphoric acid and once with acetone) and drying, the p81 filters were counted in a liquid scintillation counter.

\section{Statistical analysis}

Values are given as means with their standard errors. Due to the heterogeneity of variance between treatments (determined by Bartlett's test), data were analysed using the Kruskal-Wallis non-parametric test, and means were compared using the Mann-Whitney test (Statview Software program, version 5; Abacus Concepts, Inc., Berkeley, CA, USA). This heterogeneity was not observed for kinase contents; these findings were analysed using a classical one-way ANOVA and the means were compared by Fisher's least significant difference test to define the differences between the groups. The level of significance used was $P<0.05$.

\section{Results}

\section{Glucose and insulin levels}

In the EF chicks, glycaemia was increased from hatching to reach its maximum at $2 \mathrm{~d}$ of age $(+48 \% ; P<0.001)$, then declined at $3 \mathrm{~d}$ of age $(P<0 \cdot 05$; Fig. 1 (A)). Glycaemia was similar in the DF and EF chicks from hatching to $2 \mathrm{~d}$ of age. There was also a decrease between 2 and $3 \mathrm{~d}$ of age, which was more marked in the DF chicks than in the EF chicks. Consequently, glycaemia was lower in the DF than in the EF chicks at $3 \mathrm{~d}$ of age
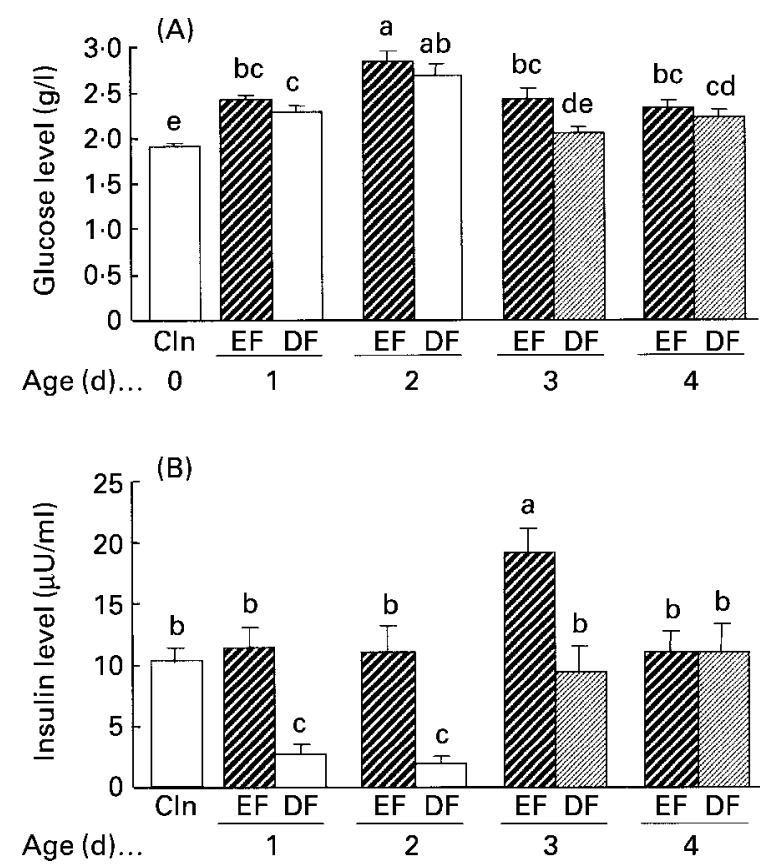

Fig. 1. Plasma glucose level (A) and plasma insulin level (B) in early-feeding (EF) and $48 \mathrm{~h}$-delayed-feeding (DF) chicks. Cln, control-hatched chicks; $(\square)$, food-deprived; (, $\mathbb{Z}$, fed. Plasma glucose levels were measured using an automated analyser and plasma insulin levels by radioimmunoassay. The values are means, with their standard errors represented by vertical bars $(n 10)$. $\mathrm{a}, \mathrm{b}, \mathrm{c}, \mathrm{d}, \mathrm{e}$ Mean values with unlike superscript letters were significantly different (Mann-Whitney test; $P<0.05$ ). 
$(P<0 \cdot 01)$. Plasma glucose concentrations became similar in the DF and EF chicks at $4 \mathrm{~d}$ of age.

Insulinaemia in the $\mathrm{EF}$ chicks remained unchanged during the first $2 \mathrm{~d}$ of feeding in the EF group (Fig. 1 (B)). At $3 \mathrm{~d}$ of age it was increased by about $0 \cdot 8$-fold $(P<0.05)$, and at $4 \mathrm{~d}$ of age insulinaemia returned to the levels measured on days 0,1 and 2 . In the DF chicks, post-hatching starvation induced higher glucose levels but lower insulin levels compared with the values measured in the control-hatched chicks $(P<0 \cdot 01)$. Insulinaemia was thus approximately five times lower than in the EF chicks at the same age $(P<0 \cdot 001)$. Since food was available, insulin levels increased by about 3.5-fold $(P<0 \cdot 01)$, reaching levels similar to those in the control-hatched chicks, but remained lower than in the 3-d-old EF chicks $(P<0 \cdot 01)$. Insulinaemia was similar in the $\mathrm{DF}$ and $\mathrm{EF}$ chicks at $4 \mathrm{~d}$ of age.

Pectoralis major muscle p70 S6 kinase activity in neonatal chicks

In the EF chicks, muscle S6K1 activity increased at $1 \mathrm{~d}$ of age (2.6-fold; $P<0.001)$ compared with the enzymic activity determined in the control-hatched chicks (Fig. 2). On day 2, S6K1 activity was not different from that of the control-hatched chicks, even though a $1 \cdot 8$-fold stimulation was recorded $(P=0 \cdot 19)$. S6K1 activity became higher on day $3(2.3$-fold; $P<0.01)$ before declining at $4 \mathrm{~d}$ of age and returning to the values measured in the controlhatched chicks. S6K1 activity in the DF chicks was lower during the $2 \mathrm{~d}$ post-hatching starvation compared with the enzymic activity determined in the controlhatched chicks $(P<0 \cdot 01)$. An increase only occurred at the beginning of feeding (i.e. $3 \mathrm{~d}$ of age) and this higher S6K1 activity $(P<0.01)$ was maintained to at least $4 \mathrm{~d}$ of age. The comparison of S6K1 activity after 1 or $2 \mathrm{~d}$ of feeding shows no significant difference between the $\mathrm{EF}$ and DF chicks (1-d-old EF chicks v. 3-d-old DF

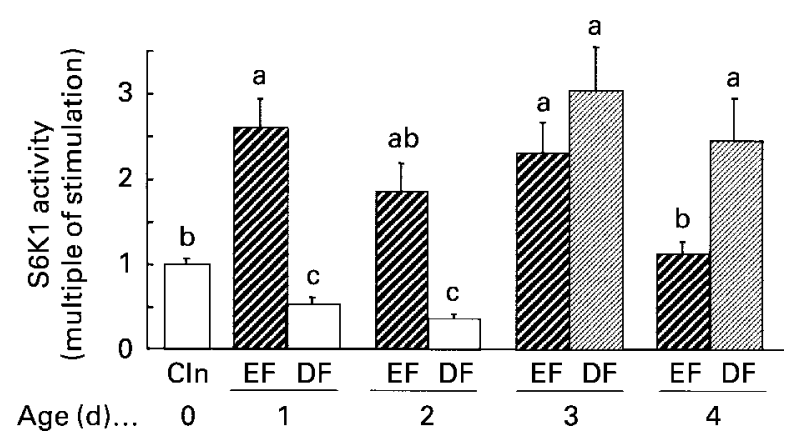

Fig. 2. p70 S6 kinase (S6K1) activity in Pectoralis major muscle of early-feeding chicks (EF) and $48 \mathrm{~h}$-delayed-feeding chicks (DF).

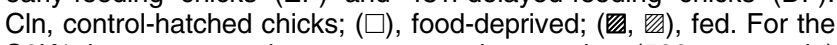
S6K1 immune complex assay, muscle samples $(500 \mu \mathrm{g}$ protein) were immunoprecipitated with anti-S6K1 antibody $(1: 50, \mathrm{v} / \mathrm{v})$ and the immune complexes were submitted to the kinase assay as described on p. 1025. The incorporation of $\left[{ }^{33}\right.$ P]ATP into a S6K1 substrate (AKRRRLSSLSRA) was quantified by liquid scintillation spectrometry. The values are means, with their standard errors represented by vertical bars $(n 10){ }^{\mathrm{a}, \mathrm{b}, \mathrm{c}}$ Mean values with unlike superscript letters were significantly different (Mann-Whitney test, $P<0.05)$. chicks, $P=0 \cdot 46 ; 2$-d-old EF chicks $v$. 4-d-old DF chicks, $P=0 \cdot 23)$.

\section{p70 S6 kinase phosphorylation on Thr389 in neonatal chicks}

S6K1 phosphorylation on the Thr389 residue in skeletal muscle of the EF and DF chicks was then investigated. The signal obtained with the phosphospecific antibody was normalised for total S6K1 content. The amount of S6K1 in neonatal chick muscle was increased from hatching to $4 \mathrm{~d}$ of age in the EF chicks $(P<0 \cdot 01$ on days 3 and 4$)$ but was unchanged in the DF chicks (Fig. 3). In the EF chicks, S6K1 phosphorylation on the Thr389 residue was increased by about 8 -fold $(P<0.01)$ at $1 \mathrm{~d}$ of age compared with the Thr389 phosphorylation level determined in the control-hatched chicks. The phosphorylation status was clearly decreased on day 2
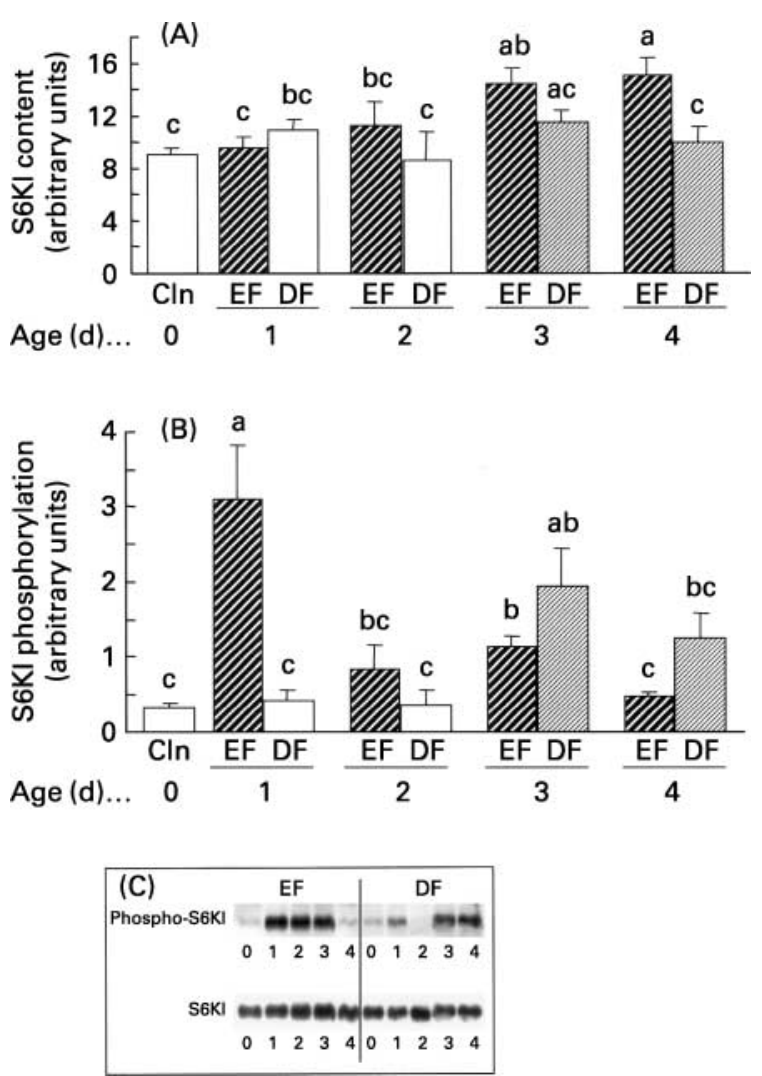

Fig. 3. p70 S6 kinase (S6K1) content (A) and Thr389 phosphorylation of S6K1 (B) in Pectoralis major muscle of early-feeding chicks (EF) and $48 \mathrm{~h}$-delayed-feeding chicks (DF). Cln, control-hatched

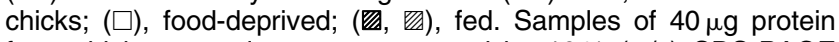
from chicken muscles were separated by $10 \%(w / v)$ SDS-PAGE and immunoblotted using anti-S6K1 and anti-phospho-S6K1 (Thr389) antibodies. The bands were visualised by an enhanced chemiluminescence Western blotting kit and quantified by Scion Image software. (C), Results from a representative blot. Samples from each condition were analysed on every blot to minimise blotto-blot variations in the results. Results of S6K1 phosphorylation were normalised for S6K1 content. The values are means, with their standard errors represented by vertical bars $(n 5)$. ${ }^{a, b, c}$ Mean values with unlike superscript letters were significantly different (Fisher's least significant difference test for kinase content and Mann-Whitney test for kinase phosphorylation; $P<0.05)$. 
to reach levels not significantly different from those observed in the control-hatched chicks $(P=0 \cdot 34)$, then it increased again on day 3 (2.4-fold; $P<0 \cdot 01)$. At $4 \mathrm{~d}$ of age, Thr389 phosphorylation returned to values measured in the control-hatched chicks. In the DF chicks, S6K1 phosphorylation on Thr389 was maintained at the basal level during the $2 \mathrm{~d}$ post-hatching starvation $(P>0 \cdot 25)$. As soon as food became available (i.e. at $3 \mathrm{~d}$ of age), the phosphorylation status of Thr389 increased by about 5 -fold $(P<0.01)$ compared with the control-hatched chicks and remained elevated on day 4 (2.8-fold increase; $P<0 \cdot 05)$. Thr389 phosphorylation was similar in the EF and DF chicks after $1 \mathrm{~d}$ of feeding (1-d-old EF chicks $v$. 3 -d-old DF chicks; $P=0 \cdot 17$ ) or after $2 \mathrm{~d}$ of feeding (2-d-old EF chicks $v$. 4-d-old DF chicks; $P=0 \cdot 25$ ).

\section{Protein kinase B phosphorylation on Ser473 in neonatal chicks}

In the present study, a significant correlation was observed when S6K1 activity was plotted against plasma insulin levels $\left(y=0.712+0.091 x, R^{2} 0.27 ; P<0.001\right)$. To determine whether insulin-signalling events upstream from S6K1 were also enhanced in the chick neonates, PKB phosphorylation in skeletal muscle was examined. The anti-PKB/Akt antibody used in the present study to determine PKB content detects total levels of endogenous Akt1, Akt2 and Akt3 proteins and does not cross-react with other related kinases. This antibody is chicken reactive (Egea et al. 2001; Stephens et al. 2001). The anti-phospho-PKB antibody recognises PKB when it is phosphorylated on Ser473 and does not cross-react with PKB phosphorylated on other residues or with related kinases such as S6K1. The PKB phosphorylation intensity was normalised for total PKB content. As observed for S6K1 content, the amount of PKB in EF chick muscle was increased from hatching to $4 \mathrm{~d}$ of age $(P<0.05$ on day 4) but was unchanged in the DF chicks (Fig. 4). The phosphorylation status of PKB in the EF group increased by 1.3 -fold $(P<0.05)$ at $1 \mathrm{~d}$ of age compared with the Ser473 phosphorylation level determined in the controlhatched chicks. Ser473 phosphorylation in 2-, 3- and 4-dold EF chicks returned to the values measured in the control-hatched chicks ( $P$ from 0.12 to 0.35 according to age). In the DF chicks, PKB phosphorylation on Ser473 was maintained at the basal level during the $2 \mathrm{~d}$ post-hatching starvation. When food was available in the DF group (on days 3 and 4), PKB phosphorylation was higher than in the control-hatched chicks (about 1.5-fold increase; $P<0.05)$. PKB phosphorylation was similar in the EF and DF chicks after $1 \mathrm{~d}$ of feeding (1-d-old EF chicks $v$. 3 -d-old DF chicks; $P=0.75)$ or after $2 \mathrm{~d}$ of feeding (2-dold EF chicks $v$. 4-d-old DF chicks; $P=0 \cdot 46$ ).

\section{Discussion}

In the present study, the possible changes in S6K1 activation were investigated in the breast muscle of neonatal chicks food-deprived for the first $48 \mathrm{~h}$ post-hatching (DF chicks) or with immediate access to food (EF chicks). S6K1 phosphorylation and activity were increased as soon as food was available, but exhibited very low levels
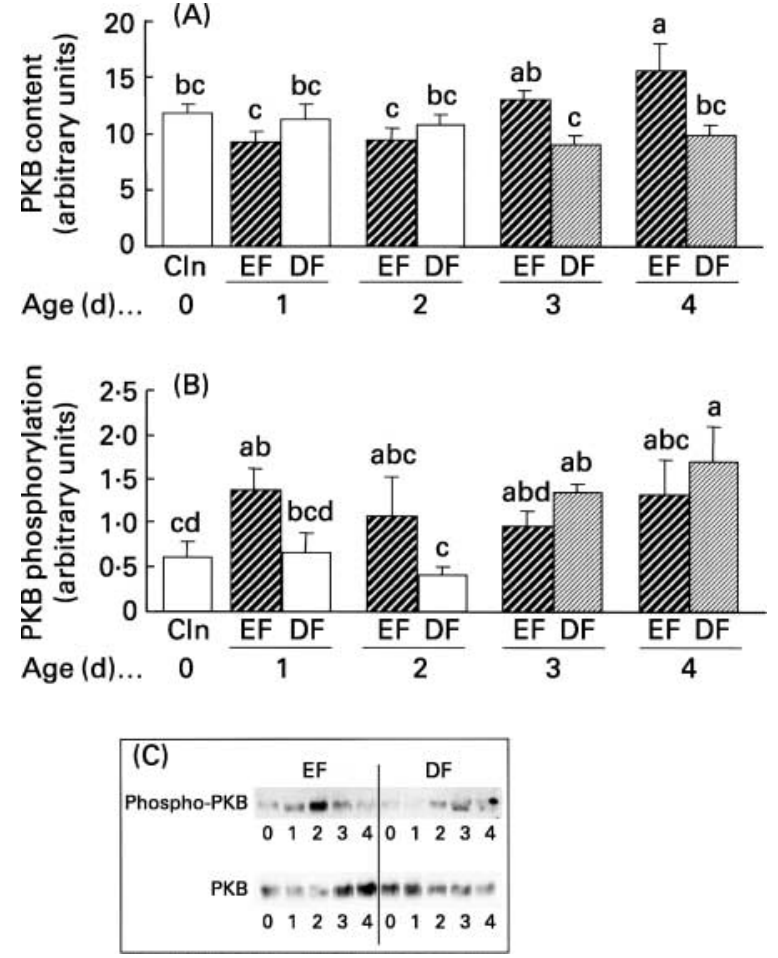

Fig. 4. Protein kinase $B(P K B)$ content $(A)$ and Ser473 phosphorylation of PKB (B) in Pectoralis major muscle of early-feeding chicks (EF) and $48 \mathrm{~h}$-delayed-feeding chicks (DF). Cln, control-hatched chicks; ( $\square$ ), food-deprived; (國), fed. Samples of $40 \mu \mathrm{g}$ protein from chicken muscles were separated by $10 \%$ (w/v) SDS-PAGE and immunoblotted using an antibody raised against PKB and phosphorylated Ser473 of PKB. Bands were visualised by an enhanced chemiluminescence Western blotting kit and quantified by Scion Image software. (C), Results from a representative blot. Samples from each condition were analysed on every blot to minimise blot-to-blot variations in results. Results of PKB phosphorylation were normalised for PKB content. The values are means, with their standard errors represented by vertical bars $(n 5)$. ${ }^{a, b, c, d}$ Mean values with unlike superscript letters were significantly different (Fisher's least significant difference test for kinase content and Mann-Whitney test for kinase phosphorylation; $P<0.05)$.

during post-hatching starvation. A relatively similar pattern was observed for PKB, a kinase upstream from S6K1. Food-related S6K1 activation was comparable in the EF and DF chicks, suggesting that this pathway was not up regulated after the starvation period.

When food was available immediately after hatching (EF chicks), a significant increase in muscle S6K1 activity was recorded on days 1 and 3 compared with the controlhatched chicks. The evolution of S6K1 phosphorylation on Thr389 in the EF chicks was the same, in agreement with the assumption that phosphorylation of Thr389 is closely correlated to S6K1 activity in vivo (Weng et al. 1995; Dufner \& Thomas 1999). Post-hatching starvation resulted in a lack of muscle S6K1 phosphorylation and activation. With regard to the well-established role of S6K1, the present study suggests that starvation during the critical posthatching period limits the efficiency of mRNA translation in muscle. Nutrients in the residual yolk not used during fetal life may not be sufficient to induce S6K1 activation in muscle so as to maintain plasma insulin concentrations at the levels observed in the control-hatched chicks. 
Furthermore, post-hatching starvation prevents the increase of ribosomal capacity (Cs, i.e. potential for protein synthesis) recorded in the muscle of chicks fed immediately after hatching (Bigot et al. 2003a), affects satellite cell proliferation (myogenic precursors present in the skeletal muscle; Halevy et al. 2000), and increases myonuclear apoptosis (Mozdziak et al. 2002). All these results agree with the reduced muscle development in the DF chicks.

The finding that S6K1 was activated after the onset of feeding in both the DF and EF chicks indicates that the activation of S6K1 in neonate chick muscle is due to changes in nutritional and hormonal status rather than to an ontogenic effect per se. Interestingly, the feedinginduced increase in S6K1 activity and phosphorylation were sustained over a relatively long period of time (days rather than hours). This model of feeding in neonatal chicks is original since it is very different from the postprandial stimulation after overnight food deprivation usually studied in the literature (Svanberg et al. 1997; Davis et al. 2000; Kimball et al. 2002). Because food is consumed throughout the day providing an almost continuous supply of nutrients in chickens (Muramatsu, 1990), there are no repeated cycles of post-absorptive and feeding states due to meals.

In the present study, a significant relationship was observed between S6K1 activity and plasma insulin levels $(P<0 \cdot 001)$. This is consistent with the fact that insulin regulates S6K1 activity in the skeletal muscles of 3week-old chickens (Bigot et al. 2003b). In addition, the supply of food increased the phosphorylation of PKB which is an upstream signalling element of S6K1 related to insulin signalling in mammals (Burgering \& Coffer, 1995). Taken together, these findings indicate that insulin is involved in S6K1 activation in chicken muscle, despite the fact that chickens exhibit particularities concerning insulin regulation. These particularities are: a relative resistance to exogenous insulin (Simon, 1989; Taouis et al. 1993), high plasma levels of glucose ( $2 \mathrm{~g} / \mathrm{l})$, and a lack of a refeeding-related response of the muscle phosphatidylinositol 3'-kinase pathway (Dupont et al. 1998). These particularities are factors of progress to understand the dysregulations observed in other species including man.

Although a correlation was found between S6K1 activity and insulinaemia, S6K1 activation occurs at day 1 in the absence of any increase in plasma insulin. Other results also suggest that insulin regulation could be altered in neonatal chicks during the first days of age. In the present study, there was an increase in plasma glucose level until $2 \mathrm{~d}$ of age in the EF chicks without changes in insulinaemia, suggesting a lack of maturity of pancreatic $\beta$-cells just after hatching. This finding is in agreement with the development of the glucose-dependent insulin secretion reported in mammals (Bliss \& Sharp, 1994). On day 3, the reduced glycaemia observed in the EF chicks was related to an increase in plasma insulin concentrations. It is noteworthy that S6K1 activity and phosphorylation on Thr389 further increased at that age in the EF chicks, concomitantly with insulinaemia. When food is available after $2 \mathrm{~d}$ of starvation (3-d-old DF chicks), a reduction of glycaemia also occurred parallel with an increase in insulinaemia and was more pronounced than that observed in the
EF chicks. This could indicate a greater insulin sensitivity of glucose metabolism induced by early malnutrition. An insulin-sensitising effect of energy restriction, undernutrition or poor fetal nutrition has previously been reported in mammals, with greater insulin-stimulated glucose uptake into skeletal muscle and adipocytes (Ozanne et al. 1996, 1997; Agote et al. 2001). Little is known about the cellular and molecular mechanisms underlying this process. An insulin-related increase in glucose transport caused by energy restriction occurred in insulin-receptor substrate (IRS)-1 knockout mice, implicating an IRS-1independent mechanism (Gazdag et al. 1999). Furthermore, energy restriction did not change the insulin stimulation of IRS-1, IRS-2 or phosphotyrosine-associated phosphatidylinositol $3^{\prime}$-kinase activity in rat muscle (Dean et al. 1998; Davidson et al. 2002). Similarly, in the present study, the response of the S6K1 pathway to feeding was not enhanced after post-hatching starvation. Thus, the signal-transduction pathways need to be clarified to understand the alterations of metabolic regulations in chickens as in mammals.

In conclusion, S6K1 is regulated by food intake in the breast muscle of neonatal broiler chicks. The feedinginduced increase in S6K1 activity is associated with its phosphorylation on Thr389 and with PKB phosphorylation on Ser473. Moreover, the present results suggest that muscle S6K1 activation is at least partly insulin dependent. In neonate chicks, a delayed access to feed induces changes in the glucose-insulin balance, indicating possibly an increase in muscle insulin action. However, early posthatching starvation defers muscle S6K1 activation without leading to any immediate compensatory stimulation. Elucidating these mechanisms has importance for fundamental physiology as well as for nutritional application.

\section{Acknowledgements}

The authors would like to thank Yves Jego (Hubbard-ISA, France) for providing the fertile pedigree eggs, Bernard Guillerm for animal care and Claude Bouchot and Michel Derouet for technical assistance (INRA, 37380 Nouzilly, France). K. B. was supported by a grant from Conseil Régional de la Région Centre, France.

\section{References}

Agote M, Goya L, Ramos S, et al. (2001) Glucose uptake and glucose transporters protein in skeletal muscle from undernourished rats. Am J Physiol 281, E1101-E1109.

Ballou LM, Luther H \& Thomas G (1991) MAP2 kinase and 70K S6 kinase lie on distinct signalling pathways. Nature 349, 348-350.

Bigot K, Mignon-Grasteau S, Picard M \& Tesseraud S (2003a) Effects of delayed food intake on body, intestine, and muscle development in neonate broilers. Poult Sci 82, 781-788.

Bigot K, Taouis M \& Tesseraud S (2003b) Refeeding and insulin regulate S6K1 in chicken skeletal muscles. J Nutr 133, 369-373.

Bigot K, Tesseraud S, Taouis M \& Picard M (2001) Alimentation néonatale et développement précoce du poulet de chair (Neonatale food and the early development of table fowl). INRA Prod Anim 14, 219-230. 
Bliss CR \& Sharp GW (1994) Development of glucose responsiveness from the fetal to the adult B-cell. In Insulin Secretion and Pancreatic B-cell Research, pp. 69-76 [PR Flatt and S Lenzen, editors]. Whitstable, Kent, UK: Eldred Smith-Gordon.

Burgering BM \& Coffer PJ (1995) Protein kinase B (c-Akt) in phosphatidylinositol-3-OH kinase signal transduction. Nature 376, 599-602.

Chamblee TN, Brake JD, Schultz CD \& Thaxton JP (1992) Yolk sac absorption and initiation of growth in broilers. Poul Sci 71, $1811-1816$.

Davidson RT, Arias EB, Cartee GD (2002) Calorie restriction increases muscle insulin action but not IRS-1-, IRS-2-, or phosphotyrosine-PI 3-kinase. Am J Physiol 282, E270-E276.

Davis TA, Fiorotto ML, Burrin DG, et al. (2002) Stimulation of protein synthesis by both insulin and amino acids is unique to skeletal muscle in neonate pigs. Am $J$ Physiol 282, E880-E890.

Davis TA, Nguyen HV, Suryawan A, Bush JA, Jefferson LS \& Kimball SR (2000) Developmental changes in the feedinginduced stimulation of translation initiation in muscle of neonatal pigs. Am J Physiol 279, E1226-E1234.

Dean DJ, Brozinick JT, Cushman SW \& Cartee GD (1998) Calorie restriction increases cell surface GLUT-4 in insulin-stimulated skeletal muscle. Am J Physiol 275, E957-E964.

Dufner A \& Thomas G (1999) Ribosomal S6 kinase signaling and the control of translation. Exp Cell Res 253, 100-109.

Dupont J, Derouet M, Simon J \& Taouis M (1998) Effect of nutritional state on the formation of a complex involving insulin receptor IRS-1, the $52 \mathrm{kDa} \mathrm{Src}$ homology/collagen protein (Shc) isoform and phosphatidylinositol 3'-kinase activity. Biochem J 335, 293-300.

Egea J, Espinet C, Soler RM, et al. (2001) Neuronal survival by neurotrophins requires calmodulin. $J$ Cell Biol 154 585-597.

Gazdag AC, Dumke CL, Kahn CR \& Cartee GD (1999) Calorie restriction increases insulin-stimulated glucose transport in skeletal muscle from IRS-1 knockout mice. Diabetes 48 1930-1936.

Halevy O, Geyra A, Barak M, Uni Z \& Sklan D (2000) Early posthatching starvation decreases satellite cell proliferation and skeletal muscle growth in chicks. $J$ Nutr 130, $858-864$.

Kawasome H, Papst P, Webb S, et al. (1998) Targeted disruption of p70(s6k) defines its role in protein synthesis and rapamycin sensitivity. Proc Natl Acad Sci USA 95, 5033-5038.

Kimball SR, Farrell PA, Nguyen HV, Jefferson LS \& Davis TA (2002) Developmental decline in components of signal transduction pathways regulating protein synthesis in pig muscle. Am J Physiol 282, E585-E592.

Kimball SR \& Jefferson LS (2002) Control of protein synthesis by amino acid availability. Curr Opin Clin Nutr Metab Care 5, 63-67.

Long W, Saffer L, Wei L \& Barrett EJ (2000) Amino acids regulate skeletal muscle PHAS-1 and S6K1 phosphorylation independently of insulin. Am J Physiol 279, E301-E306.
Mozdziak PE, Evans JJ \& McCoy DW (2002) Early posthatch starvation induces myonuclear apoptosis in chickens. $J$ Nutr 132, 901-903.

Murakami H, Akiba Y \& Horiguchi M (1992) Growth and utilisation of nutrients in newly-hatched chicks with or without removal of residual yolk. Growth Dev Aging 56, 75-84.

Muramatsu T (1990) Nutrition and whole-body protein turnover in the chicken in relation to mammalian species. Nutr Res Rev 3, 211-228.

Noy Y \& Sklan D (1999) Different types of early feeding and performance in chicks and poults. J Appl Poult Res 8, 16-24.

Ozanne SE, Nave BT, Wang CL, Shepherd PR, Prins J \& Smith GD (1997) Poor fetal nutrition causes long-term changes in expression of insulin signaling components in adipocytes. Am $J$ Physiol 273, E46-E51.

Ozanne SE, Wang CL, Coleman N \& Smith GD (1996) Altered muscle insulin sensitivity in the male offspring of protein-malnourished rats. Am J Physiol 271, E1128-E1134.

Peyrollier K, Hajduch E, Blair AS, Hyde R \& Hundal HS (2000) L-leucine availability regulates phosphatidylinositol 3-kinase, S6K1 and glycogen synthase kinase-3 activity in L6 muscle cells: evidence for the involvement of the mammalian target of rapamycin (mTOR) pathway in the L-leucine-induced upregulation of system A amino acid transport. Biochem J 350, $361-368$.

Proud CG (2002) Regulation of mammalian translation factors by nutrients. Eur J Biochem 269, 5338-5349.

Ruffier L, Crochet S \& Rideau N (1998) Insulin release by islets of Langerhans isolated from dorsal and ventral lobes of chicken pancreas. Ann NY Acad Sci 839, 553-555.

Shah OJ, Anthony JC, Kimball SR \& Jefferson LS (2000) 4EBP1.and S6K1: translational integration sites for nutritional and hormonal information in muscle. Am $J$ Physiol 279, E715-E729.

Simon J (1989) Chicken as a useful species for the comprehension of insulin action. Crit Rev Poult Biol 2, 121-148.

Stephens LR, Anderson KE \& Hawkins PT (2001) Src family kinases mediate receptor-stimulated, phosphoinositide 3kinase-dependent, tyrosine phosphorylation of dual adaptator for phosphotyrosine and 3-phosphoinositides-1 in endothelial and B cell lines. J Biol Chem 276, 42767-42773.

Suryawan A, Nguyen HV, Bush JA \& Davis TA (2001) Developmental changes in the feeding-induced activation of the insulinsignaling pathway in neonatal pigs. Am $J$ Physiol 281, E908-E915.

Svanberg E, Jefferson LS, Lundholm K \& Kimball SR (1997) Postprandial stimulation of muscle protein synthesis is independent of changes in insulin. Am J Physiol 271, E841-E847.

Taouis M, Derouet M, Chevalier B \& Simon J (1993) Corticosterone effect on insulin receptor number and kinase activity in chicken muscle and liver. Gen Comp Endocrinol 89, 167-175.

Weng QP, Andrabi K, Kozlowski MT, Grove JR \& Avruch J (1995) Multiple independent inputs required for activation of the p70 S6 kinase. Mol Cell Biol 15, 2333-2340. 